\title{
CARACTERIZAÇÃO E ANÁLISE DO PERFIL COMO \\ GÊNERO EM 'SINATRA ESTÁ RESFRIADO’
}

\author{
Michelle Moreira Braz ${ }^{1}$
}

Antonio Carlos Sardinha ${ }^{2}$

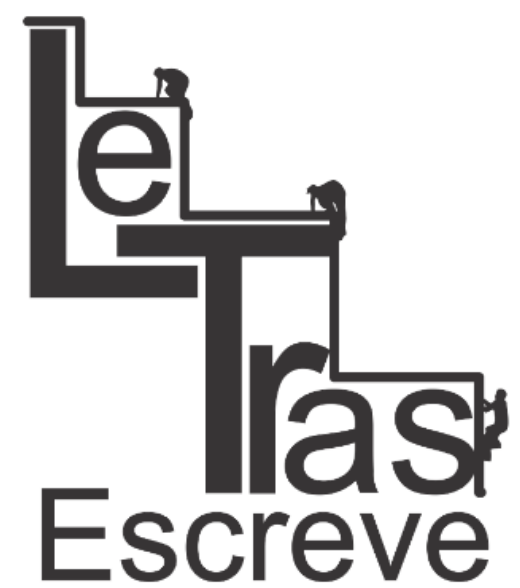

(ISSN 2238-8060)
Abstract: The apprehension of the general characteristics, strategies and delineations of the production of the profile as narrative produced by the reporter from the technical and aesthetic appropriation in the construction of meaning operated by journalism in the linguistic / discursive specificities is a question in itself, Theoretical and practical. Understanding the conceptual dimension of the profile as a genre peculiar to journalism and elaborating through the techniques of reporting this narrative demands problematization that reaches, above all, the instance of production of meaning, operated by the reporternarrator. In this article, the interest is to understand the profile as a genre in the perspective of Mikhail Bakhtin, considering the theoretical-methodological approach of the Russian theorist, from the analysis

${ }^{1}$ Doutoranda do Programa de Pós-Graduação em Comunicação (FAAC/UNESP) e professora substituta do Departamento de Comunicação Social, Unesp, Campus Bauru. E-mail: michellemoreirabraz@gmail.com

2 Doutorando no Programa de Pós-Graduação em Comunicação - UNESP, professor do Curso de Jornalismo da Universidade Federal do Amapá. E-mail: sardinhajor@yahoo.com.br

https://periodicos.unifap.br/index.php/letras

Macapá, v. 8, n. I, Io sem., 2018 
of the profile "Frank Sinatra has a cold", produced by journalist Gay Talese for Esquire magazine in April 1966. In general terms, the understanding of the characteristics of the production of discourse in the profile makes it a conceptual element to reflect on the making of journalism, ethics, construction of a character in transit with the public and private sphere, positions - and power - in relations between journalist and profiling.

Keywords: Journalism; Profile; Genre; Mikhail Bakhtin.

\section{Introdução}

O perfil como uma narrativa peculiar que trabalha com a construção/representação da fonte-personagem a partir do uso e apropriação de recursos estéticos e técnicos característicos da linguagem jornalística, bem como de diversas estratégias ficcionais consagradas, o configuram como gênero que estimula inquietações do ponto de vista teórico-prático no campo do jornalismo.

A apreensão das características gerais, estratégias e delineamentos da produção dessa narrativa por parte do repórter nos permitem observar o perfil sobre diversas instâncias (produção, circulação e recepção) de produção de sentido. Neste artigo,

o interesse é compreender o perfil como gênero na perspectiva de Mikhail Bakhtin, considerando abordagem teóricometodológica do autor, a partir da análise do perfil Frank Sinatra está resfriado (Frank Sinatra has a cold), produzido pelo jornalista Gay Talese. ${ }^{3}$

Destaca-se que o perfil em tela é destaque pela forma como foi construído por Gay Talease. Em 1965, o jornalista foi a Los Angeles, Califórnia, para produzir um perfil de Frank Sinatra para

\footnotetext{
3 o perfil completo está disponível para consulta no link https://pt.slideshare.net/aulasdejornalismo/frank-

sinatraestaresfriadotextointegral-1-13064614. Acesso em 10 abr 2017.
}

https://periodicos.unifap.br/index.php/letras

Macapá, v. 8, n. I, Io sem., 2018 


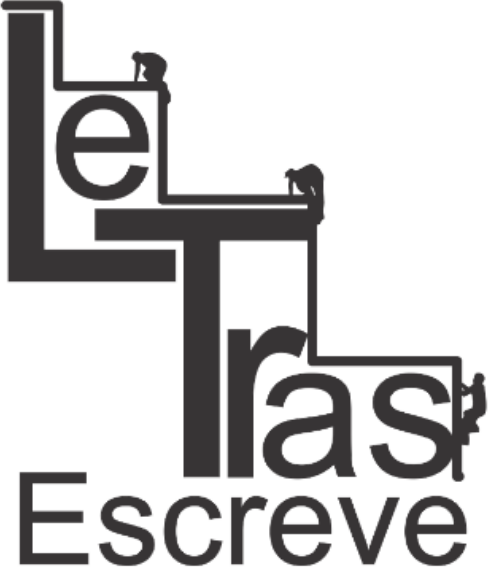

(ISSN 2238-8060)

a Revista Esquire.

Um resfriado "impede o contato" e a densidade de possíveis entrevistas, mas o perfil acabou sendo produzido, a partir da observação do artista e por meio da entrevista e testemunho de pessoas próximas ao cantor. O material foi destaque e chamou a atenção de leitores pela capacidade de registro que revelou um perfil do Sinatra não muito conhecido, sendo considerado um dos marcos da produção jornalística no contexto do New Journalism. ${ }^{4}$

Pretendemos observar o perfil de Frank Sinatra retratado por Gay Talese intitulado 'Frank Sinatra has a cold', sob uma perspectiva metodológica que observará o referido perfil, a partir de duas instâncias que definem o gênero na perspectiva de Mikhail Bakhtin (2003), a saber: a) conteúdo temático e b) composição

Conceitualmente, o entendimento é de que o discurso se faz a partir da construção de enunciados concretos que se mantêm presentes de forma relativamente estáveis em um gênero. Identificar essa regularidade no perfil é uma tentativa de compreendê-lo como gênero jornalístico de natureza peculiar, considerando elementos destacados no produto jornalístico em análise, com base nas instâncias acima destacadas. Entendemos que essa contribuição lança elementos para caracterizar o perfil como gênero dentro do campo jornalístico.

Nesse sentido, dividimos a reflexão em três partes. Em um primeiro momento, são apresentados os fundamentos conceitu-

\footnotetext{
${ }^{4}$ Em linhas gerais, o New Journalism foi um movimento que se consolida no início da década de 1960 nos Estados Unidos, expressando uma ação de jornalistas que adotaram outra perspectiva para cobertura do cotidiano, privilegiando reportagens de interesse humano, com estilo textual mais livre, com experimentações que se apropriavam dos recursos literários para compor narrativas distintas da cobertura factual, de interesse imediato.
}

https://periodicos.unifap.br/index.php/letras

Macapá, v. 8, n. I, Io sem., 2018 


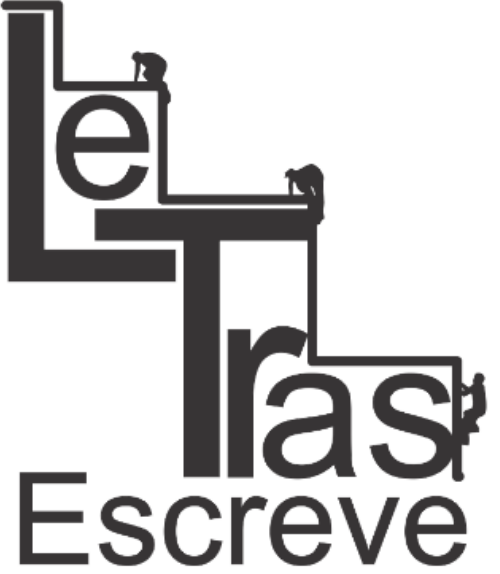

(ISSN 2238-8060)

ais e históricos que caracterizam o perfil como gênero no jornalismo, bem como as divergências de sua classificação. Em seguida, apontamos aspectos metodológicos que subsidiam a análise do perfil 'Frank Sinatra has a cold' e, por fim, a trajetória analítica com as respectivas considerações finais.

\section{Possíveis caracterizações ao gênero perfil no jornalismo}

Não apenas ao tratarmos do gênero perfil, mas numa perspectiva teórica, o conceito de gênero fomenta certa polêmica. Os motivos das controvérsias são devidos ao fato do termo gênero transmitir diferentes e difusos significados acumulados ao longo da história e, especialmente, no âmbito dos estudos literários. Além disso, o termo circula no mundo das artes tanto como no cinema e na música. A palavra gênero vem do latim vulgar generu, acusativo de generus pelo latim clássico genus, generis, que significa raça, origem, tronco: conjunto de seres que têm origem comum e semelhanças naturais; família, espécie.

Os gêneros estão presentes em todas as ações humanas que são mediadas pela atividade discursiva. Alguns gêneros são mais livres, como os gêneros das interações cotidianas; outros são mais padronizados ou "formatados", como, por exemplo, os gêneros falados e escritos usados nas burocracias institucionais, como explica Maria Inez Silveira (2005, p. 38).

Enquanto instrumentos autênticos de ação e interação sócio discursiva, a aplicabilidade dos gêneros está diretamente relacionada aos aspectos culturais e ideológicos, podendo surgir, evoluir e desaparecer a mercê da evolução das práticas sociais das comunidades que os usam, em todos os âmbitos da atividade

https://periodicos.unifap.br/index.php/letras

Macapá, v. 8, n. I, Io sem., 2018 
humana. Em outras palavras, reconhece-se que os gêneros nascem, desenvolvem-se e decaem, apesar de manterem um aspecto de regularidade e de "estabilidade" em vigor numa determinada cultura. Assim, todos os gêneros têm contextos ou situações às quais eles são moldados, ajustados, e nas quais são tipicamente encontrados.

A noção de gênero como entidade do discurso já aparece em uma importante obra de Bakhtin, Marxismo e Filosofia da Linguagem. Certamente, tal obra representa um marco inicial para a revitalização dos gêneros. Nas passagens onde a noção de gênero discursivo já se pronuncia, encontra-se o seguinte trecho:

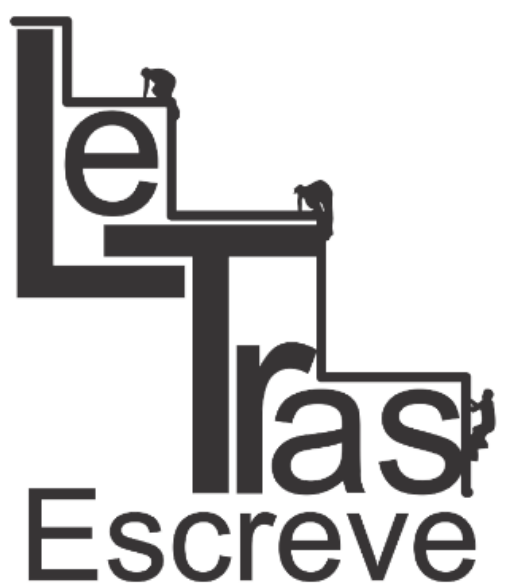

(ISSN 2238-8060)
Toda situação inscrita duravelmente nos costumes possui um auditório organizado de certa maneira e consequentemente um certo repertório de pequenas fórmulas correntes. (...) As fórmulas da vida corrente fazem parte do meio social, são elementos de festa, dos lazares, das relações que se travam no hotel, nas fábricas, etc. (...) Assim, encontram-se diferentes formas de construção de enunciações nos lugares de produção de trabalho e nos meios de comércio. (BAKHTIN, 1992, p. 126)

Dessa maneira, os gêneros do discurso são instâncias em que se verifica certa tensão entre essas forças, resultando daí um "equilíbrio instável" ou uma "instabilidade relativa", fazendo com que os gêneros não só permaneçam, mas também se revigorem, de acordo com os contextos enunciativos e as variações socioculturais e político-ideológicas que ocorrem nas comunidades em que circulam.

\subsection{0 perfil como gênero jornalístico}

Segundo a sistematização das modalidades textuais jorna-

https://periodicos.unifap.br/index.php/letras

Macapá, v. 8, n. I, Io sem., 2018 


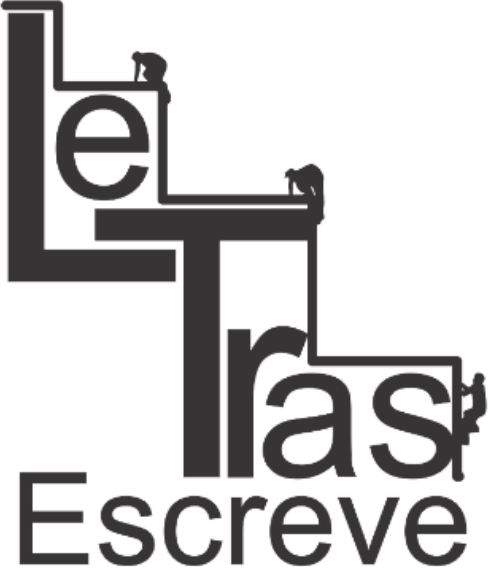

(ISSN 2238-8060)

lísticas, não identificamos, até o presente momento, o perfil como um gênero jornalístico "autônomo". Entre os estudos dos gêneros jornalísticos é frequente determiná-lo como uma expansão - humana e próspera - do gênero entrevista. Porém, tal categorização não é consensual: podemos também localizar a definição do perfil como um expoente do gênero reportagem, uma vez que geralmente agrega uma multiplicidade de fontes, além de uma entrevista direta com o entrevistado, a fim de revelar e caracterizar determinado perfil e "visão de mundo".

De qualquer maneira, e obrigatoriamente, um perfil é subsidiado por uma série de entrevistas. Para Cremilda Medina (1995), a entrevista pode ser apenas uma eficaz técnica para conseguir respostas pré-pautadas por um questionário. Todavia, Medina enfatiza que se, encarada como uma mera técnica, o ato de entrevistar "não atinge os limites possíveis da inter-relação, ou, em outras palavras, do diálogo" (1995, p. 17-18). Assim, a consciência profissional do jornalista está para a técnica da entrevista como a comunicação humana está para o diálogo. A entrevista, nas suas diferentes aplicações, engloba uma técnica de interação social, de interpenetração informativa, quebrando assim isolamentos grupais, individuais, sociais; e também pode servir para "a pluralização de vozes e à distribuição democrática de informação."

Além disso, a entrevista pode ultrapassar os limites da força de experiências. Para o filósofo Martin Buber, "o diálogo que atinge a interação humana criadora, ou seja, ambos os participes do jogo da entrevista interagem, se modificam, se revelam, crescem no conhecimento do mundo e deles próprios"(BUBER apud MEDINA, 1995, p.8). Presumindo essa "interação" que surge na

https://periodicos.unifap.br/index.php/letras

Macapá, v. 8, n. I, Io sem., 2018 
relação entrevistador e entrevistado pode-se dizer:

A experiência de vida, o conceito, a dúvida ou o juízo de valor do entrevistado, transforma-se numa pequena ou grande história que decola do indivíduo que a narra para se consubstanciar em muitas interpretações. A audiência recebe os impulsos do entrevistado, que passam pela motivação desencanada pelo entrevistador, e vai se humanizar, generalizar no grande rio da comunicação anônima. Isto, se a entrevista se aproximou do diálogo interativo. (MEDINA, 1995, p. 6)

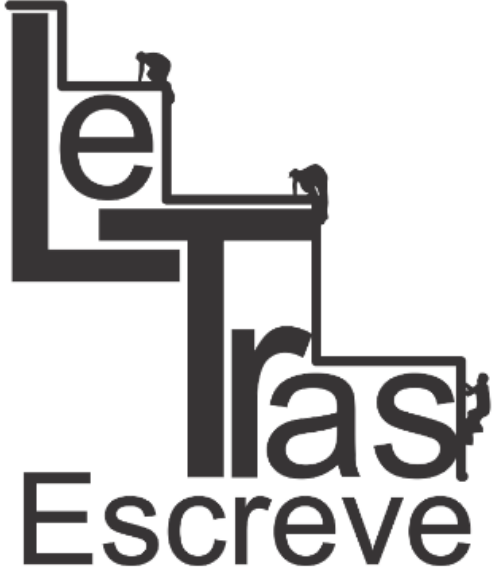

(ISSN 2238-8060)

Primeiro, pesa o grupo delimitado pelo estágio histórico de técnica comunicacional. Segundo, o nível de interação social almejado pelo entrevistador. Terceiro, suas possibilidades de criação e de ruptura com as rotinas empobrecedoras das empresas e instituições comunicacionais. Quarto, um propósito que ultrapassa os limites da técnica imediatista, ou seja, a tentativa de desvendamento do real, uma atitude de profunda especulação acerca da pauta. (MEDINA, 1995, p. 27)

No livro Entrevista - o diálogo possível, Medina expõe ainda alguns itens que, segundo ela, enriquecem o comportamento do entrevistador. São eles: a pré-pauta (ideia matriz); o preparo do entrevistador, isto é, seu repertório acumulado que remete à sua visão social, político e econômica, bem como sua sensibilidade e, finalmente, a personalidade do próprio entrevistador, que deve possuir uma "personalidade dialógica, dotada de agilidade e raciocínio rápido."

https://periodicos.unifap.br/index.php/letras

Macapá, v. 8, n. I, Io sem., 2018 
Já em relação à interação entrevistador-entrevistado, a autora sugere três comportamentos a serem adotados: consciência de que a entrevista é uma situação psicossocial, de complexidade indiscutível; relevar a personalidade do entrevistado e saber como reagir a ele, uma vez que sua atitude pode ser "monolítica, autoritária, agressiva" e uma "dinâmica de bloqueio e desbloqueio", que possibilita desencadear as ideias e estabelecer o diálogo. A fim de que essa relação seja estabelecida, alguns traços devem ser inerentes ao entrevistador competente: sensibilidade aguçada, toque criador para situações inusitadas e criatividade. Sobre essa interação, Medina explana:

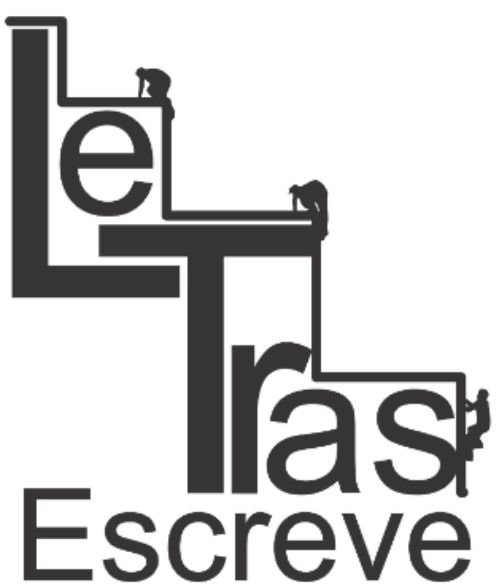

(ISSN 2238-8060)

Desenvolver a técnica da entrevista nas suas virtudes dialógicas não significa uma atitude idealista. (...) Sua maior ou menor está diretamente relacionada com a humanização do contato interativo: quando, em um desses raros momentos, ambos - entrevistado e entrevistador - saem "alterados" do encontro, a técnica foi ultrapassada pela "intimidade" entre o EU e TU. Tanto um como outro se modificaram, alguma coisa aconteceu que os perturbou, fez-se luz em certo conceito e comportamento, elucidou-se determinada autocompreensão ou compreensão do mundo. Ou seja, realizou-se o Diálogo Possível. (MEDINA, 1995, p.7)

Assim, a entrevista, e consequentemente a feitura textual de um perfil, para ser um instrumento enriquecedor na matéria jornalística, deve ser encarada como uma situação inter-humana, na qual o diálogo se direciona para a figura do entrevistado. Dessa maneira, ocorrerá uma "liberação e desbloqueamento", deixando a relação fluir e alcançando, posteriormente, a autoelucidação.

Já no ensaio "A entrevista nas Ciências Sociais, no Rádio e Televisão", o pesquisador francês Edgar Morin classifica a entre-

https://periodicos.unifap.br/index.php/letras

Macapá, v. 8, n. I, Io sem., 2018 


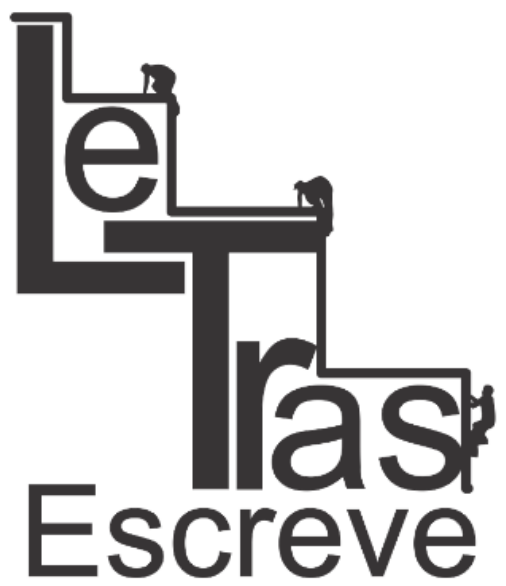

(ISSN 2238-8060) vista em dois grandes grupos: entrevistas cujo objetivo é "espetacularizar" o ser humano e entrevistas que esboçam a intenção de compreendê-lo. A partir dessa primeira classificação, Morin enumera quatro tipos de subgêneros ${ }^{5}$ : entrevista-rito, responsável pela validação de determinada cerimônia; entrevista anedótica cujo conteúdo "se situa no nível dos mexericos"; entrevistadiálogo, que corresponde a uma busca em comum, na qual entrevistador e entrevistado colaboram no sentido de trazer à tona uma "verdade" que pode dizer respeito à pessoa do entrevistado ou a um problema; neoconfissões, entrevista em que o "entrevistador se apaga diante do entrevistado", tangendo a profundidade da psicologia social.

A partir das considerações de Edgar Morin, Cremilda Medina se utiliza da mesma classificação dos dois grandes grupos de entrevistas (espetacularização e compreensão). Entretanto, no âmbito dos subgêneros lança uma nova perspectiva.

Para Medina (1995), nos subgêneros da "espetacularização" são: perfil do pitoresco, que consiste numa caricatura do entrevistado; perfil do inusitado, na qual "procura-se extrair dela o que a caracterizaria, mesmo que à força, como excêntrica, exótica"; perfil da condenação, comum no setor policial do jornalismo que reduz o entrevistado no maniqueísmo entre bandido ou mocinho; e, por último, perfil da ironia "intelectualizada", que "extrai da pessoa uma forma de condenação" por meio da contestação de suas idéias. Já nos subgêneros da "compreensãoaprofundamento" temos: entrevista conceitual, que busca bagagem informativa; entrevista/enquete cujo "tema é o fundamental

\footnotetext{
${ }^{5}$ MORIN, Edgar. "A entrevista nas Ciências Sociais, no Rádio e Televisão". In: MOLES, Abraham A. et. alli. Linguagem da Comunicação de Massa. Petrópolis: Vozes, 1973. p. 128-129.
} 


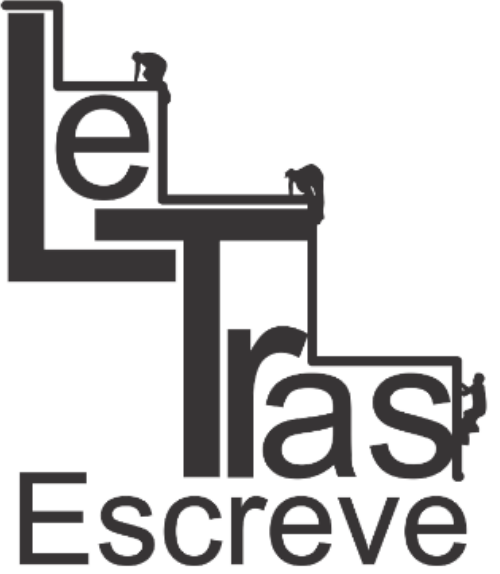

(ISSN 2238-8060) da pauta e procura-se mais de uma fonte para depor em relação ao tema"; entrevista investigativa, "aquela que investiga onde a informação não está ao acesso do jornalista"; confrontaçãopolemização, que se configura em debate, mesa-redonda, simpósio, painel ou seminário sobre determinado tema polêmica; e, perfil humanizado, entrevista que "mergulha no outro para compreender seus conceitos, valores, comportamentos, histórico de vida".

No livro A reportagem: teoria, técnica de entrevista e pesquisa jornalística, Nilson Lage classifica a entrevista jornalística em relação aos objetivos e às circunstâncias de realização.

Segundo Lage (2002), do ponto de vista dos objetivos, a entrevista pode ser dividida em: entrevista ritual, na qual "está mais centrada na exposição (da voz, da figura) do entrevistado do que no que ele tem a dizer"; entrevista temática, que procura abordar um tema sobre o qual se supõe que o entrevistado tenha "condições e autoridade para discorrer"; entrevista testemunhal, que compreende no relato do entrevistado sobre algo que ele assistiu ou participou; em profundidade, entrevista em que o objetivo se encontra "na figura do entrevistado, a representação de mundo que ele constrói." Aqui, vale ressaltar que a classificação de Nilson Lage para a entrevista em profundidade pode ser facilmente traduzida como o perfil jornalístico encontrado em diversas publicações mundo afora, já que se norteia como objetivo a construção - e os efeitos de realidade - dos aspectos biográficos e perspectivas de mundo do perfilado.

Sobre as circunstâncias de realização da entrevista, Lage (2002) classifica em: entrevista ocasional, aquele que não é combinado com o entrevistado previamente; entrevista confronto, na

https://periodicos.unifap.br/index.php/letras

Macapá, v. 8, n. I, Io sem., 2018 


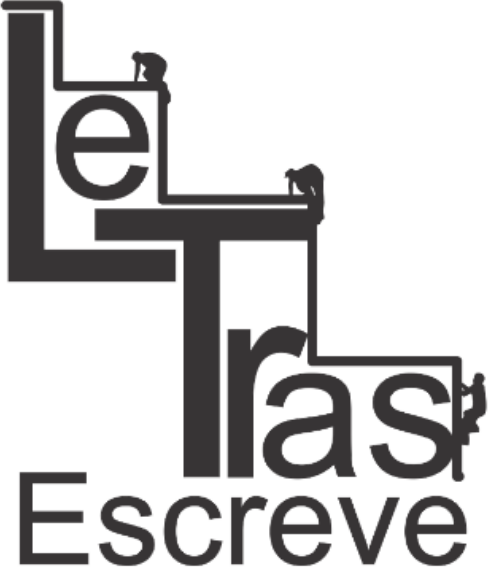

(ISSN 2238-8060) qual "o repórter assume o papel de inquisidor, despejando sobre o entrevistado acusações e contra-argumentando"; entrevista coletiva, aquela em que o entrevistado é submetido a perguntas de vários repórteres de diferentes veículos; e, por último, entrevista dialogal, que configura "a entrevista por excelência" cujo resultado é o aprofundamento e detalhamento dos pontos abordados. No caso de um perfil, observa-se que tais modalidades de "realização da entrevista" geralmente são combinatórias, já que dependem de uma gama investigativa para uma compreensão mais satisfatória das idiossincrasias (e ambiguidades) do perfilado.

Já o gênero reportagem procura romper a mera descrição dos fatos, promovendo uma narrativa que veio para detalhar os acontecimentos, situando-os em aspectos "motivacionais e implicacionais", ou seja, o porquê do fato, o seu desdobramento e o desfecho. A forma de apresentação de reportagens nos jornais e revistas varia: ora é descritiva, ora narrativa, expositiva, e até dissertativa. Constrói-se com a coleta de informações por meio das entrevistas e análise de diferentes ângulos do fato. Mas a reportagem inicia-se com a presença do repórter no local onde se desenvolvem as ações, para resgate de dados e depoimentos dos envolvidos. Assim, a entrevista e a descrição se casam para construir o texto. Como exemplo, a presença de Euclides da Cunha, em 1897, no cenário da Guerra de Canudos, como correspondente de $O$ Estado de S. Paulo. Sobre tal fato, Marcelo Bulhões enfatiza que:

Na dilatação do evento noticioso, a reportagem pode estender-se como uma realização descritiva, na composição astuciosa de uma personagem ou na colocação de um cenário. Ou desdobrar-se plenamente na 
narratividade, em que estão implicados personagens em processo de mudança de estado. É desse modo que ela ensaia alguma proximidade com realizações da prosa de ficção ou transporta marcas da própria literariedade. (2007, p. 45)

Ainda que não tenhamos unanimidade teórica sobre as caraterísticas do gênero perfil, o pesquisador Muniz Sodré reforça que um "aspecto estável" ao gênero é o enfoque na personagem a ser retratado pelo jornalista:

Em jornalismo, perfil significa enfoque na pessoa seja uma celebridade, seja um tipo popular, mas sempre o focalizado é o protagonista de uma história: sua própria vida. Diante desse herói (ou anti-herói), o repórter tem, via de regra, dois tipos de comportamento: ou mantém-se distante, deixando que o focalizado se pronuncie, ou compartilha com ele um determinado momento e passa ao leitor essa experiência (SODRÉ, 1986: 126).

Ricardo Kotscho, jornalista e pesquisador da área de Comunicação, também discute, em A Prática da Reportagem (2003), o perfil jornalístico ao problematizar que tal gênero não necessariamente significa apenas uma narrativa uma pessoa física:

Filão mais rico das matérias chamadas humanas, o perfil dá ao repórter a chance de fazer um texto mais trabalhado - seja sobre um personagem, um prédio ou uma cidade. Para isso, é necessário que ele se municie previamente sobre o tema de que vai tratar: para ir fundo na vida de uma pessoa ou de um lugar, é preciso, antes de mais nada, conhecê-lo bem (KOTSCHO, 2003: 42).

A presença dessas citações não significa que a bibliografia sobre o tema seja extensa. De fato, é importante ressaltar que poucos são os estudiosos dedicados ao gênero perfil. Verifica-se,

https://periodicos.unifap.br/index.php/letras

Macapá, v. 8, n. I, Io sem., 2018 
por exemplo, que uma das obras mais citadas sobre o perfil jornalístico - Perfil e como escrevê-los, de Sergio Vilas Boas - apresenta, na verdade, apenas um capítulo especificando as possíveis particularidades do gênero ${ }^{6}$. Ademais, e no contexto da produção científica brasileira, revela-se a carência de uma teorização sólida do perfil como uma modalidade textual presente no campo jornalístico.

\section{Apresentação do objeto empírico e pressupostos metodológi- $\cos$}

Pretendemos observar o perfil de Frank Sinatra retratado

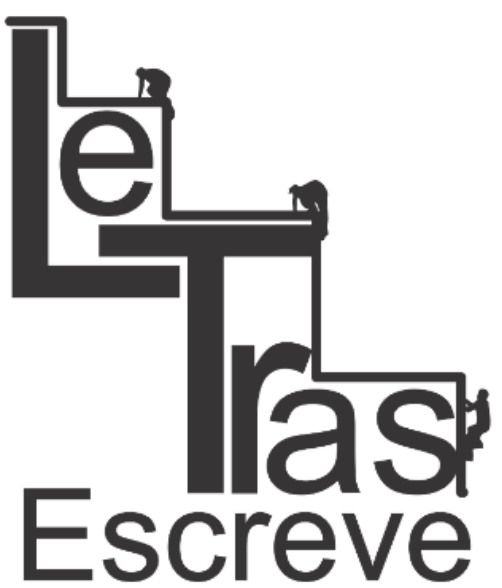

(ISSN 2238-8060) por Gay Talese intitulado "Frank Sinatra has a cold", sob uma perspectiva metodológica que observará o referido perfil, a partir das instâncias que definem o gênero na perspectiva de Bakhtin (2003), a saber: a) conteúdo temático e b) composição.

O perfil elaborado por Gay Talese foi publicado na revista Esquire, em 1966, e ficou conhecido por ser produzido sem que o perfilado fosse entrevistado pelo jornalista. O trabalho de apuração começou 1965 e durou mais de um ano.

Diante da inviabilidade de uma entrevista face-a-face com o perfilado, o que faz desse perfil especificamente uma produção peculiar, considerando ser essa a modalidade de entrevista central para a elaboração de um perfil, Gay Talese entrevistou dezenas de pessoas próximas ao artista, incluindo familiares, amigos, assessores e colegas de trabalho. Além disso, observou o cantor nos espaços onde costumava frequentar. A mescla de entrevistas

\footnotetext{
${ }^{6}$ Observa-se que a obra Perfis e como escrevê-los constitui mais um "livro testemunho" de Sergio Vilas Boas sobre as agruras de escrever perfis, uma vez que o autor apresenta na obra uma coletânea de 12 perfis de sua autoria com os respectivos comentários destas produções.
}

https://periodicos.unifap.br/index.php/letras

Macapá, v. 8, n. I, Io sem., 2018 


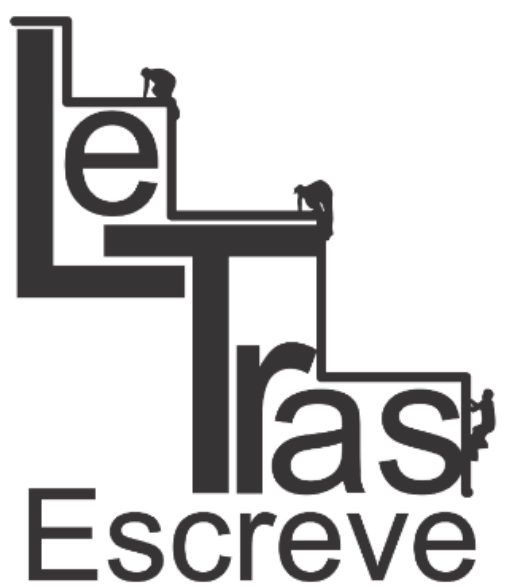

(ISSN 2238-8060)

realizadas durante o processo de apuração rendeu milhares de páginas e semanas para organizar o material até a publicação.

Bakhtin afirma, no livro Estética da criação verbal, que a riqueza e a variedade dos gêneros do discurso são infinitas, ressaltando a sua heterogeneidade. Os gêneros se diversificam, vão se ampliando e se tornando cada vez mais complexos à medida que a sociedade vai se tornando mais complexa e as próprias atividades humanas vão se ampliando, se diversificando e se tornando mais sofisticadas.

\begin{abstract}
Ficaríamos tentados a pensar que a diversidade dos gêneros é tamanha que não há e não poderia haver um terreno comum para seu estudo: com efeito, como colocar no mesmo terreno de estudo fenômenos tão díspares como a réplica cotidiana (que pode reduzir-se a uma palavra) e o romance ( em vários tomos), a ordem padronizada que é imperativa já por sua entonação e a obra lírica profundamente individual, etc? (1992, p. 280)
\end{abstract}

Na perspectiva de Bakhtin (1992), como resultado da interação entre indivíduos existe a enunciação dialógica, um processo que digamos permeia a comunicação entre pessoas e presume que os sujeitos não esperam respostas dos outros, mas constroem seus discursos pelo e por meio do que se espera do outro.

Conforme Rodrigues (2004, p.423), como tipos temáticos, estilísticos e composicionais dos enunciados individuais, os gêneros se constituem historicamente a partir de novas situações de interação verbal da vida social que (relativamente) se estabilizam no interior das diferentes esferas sociais .

Nesse sentido, destacamos que apesar da natureza mutável pela dinâmica sócio-histórica dos gêneros do discurso, há elementos interligados que permanecem:

https://periodicos.unifap.br/index.php/letras

Macapá, v. 8, n. I, Io sem., 2018 


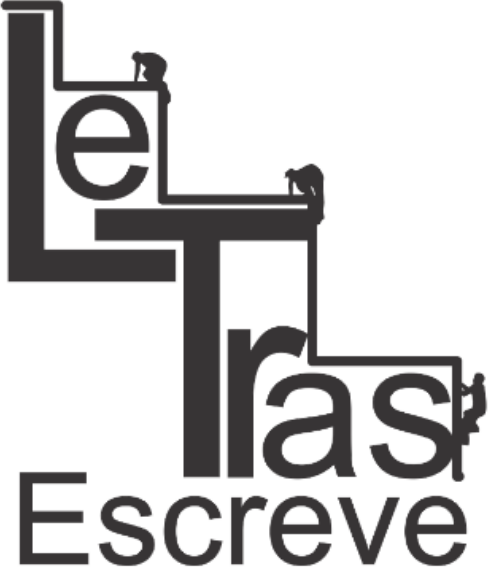

(ISSN 2238-8060)

a) o conteúdo temático (que não pode ser confundido com assunto) corresponde aos diferentes eixos de atribuições de sentido em um determinado gênero, ou seja, conjunto de temas;

b) composição (ou organização composicional) refere-se à estruturação interna do enunciado, a partir do modo como é reconhecido em uma dada sociedade;

c) estilo está ligado aos recursos lingüísticos usados pelo enunciador na perspectiva de ter atendida sua expectativa de resposta do sujeito que o ouve.

Sob essa perspectiva bakhtiniana de gêneros discursivos, observaremos o perfil elaborado por Talese sobre Frank Sinatra, destacando conteúdo temático e composição presentes no perfil. $^{7}$

O pressuposto de pesquisa que motiva a análise envolve uma tentativa de apreender as características do perfil como um gênero discursivo, observando como objeto empírico o perfil considerado marco para a caracterização do New Journalism, como fazer "alternativo" que resignifica a prática jornalística com ecos na contemporaneidade.

Essa tentativa de uma breve análise busca compreender as características de produção do discurso no perfil torna um elemento conceitual para operar uma conceituação mais ampla desse gênero no campo jornalístico, considerando as especificidades de configuração e caracterização do perfil como narrativa no jornalismo. Além disso, é importante observar as características

\footnotetext{
${ }^{7}$ Outra instância presente na análise de gênero na perspectiva bakhtiniana é o estilo. Entretanto, como a proposta de análise presume observar uma única amostra de perfil, metodologicamente a apreciação dessa instância fica comprometida, considerando que o estilo como instância de caracterização de um gênero e de um autor específico demanda análise comparada e pormenorizada de outros exemplares da produção do mesmo autor, assim, optamos por não considerá-la nesta presente análise.
}

https://periodicos.unifap.br/index.php/letras

Macapá, v. 8, n. I, Io sem., 2018 
norteadoras de produção e materialização do perfil- enquanto um compêndio de interações sociais, ora mais restritas as técnicas jornalísticas, que se alavancam em uma trama textual, a fim de organizar - para um leitor - o que é esse personagem a partir de registros e efeitos de realidade, bem como, e dentro do possível da pesquisa jornalística, sua persona, isto é, a(s) máscara(s) que abarca o conjunto de idiossincrasias que faz a personalidade de uma pessoa.

\section{Análise de "Frank Sinatra has a cold"}

\subsection{Conteúdo temático}

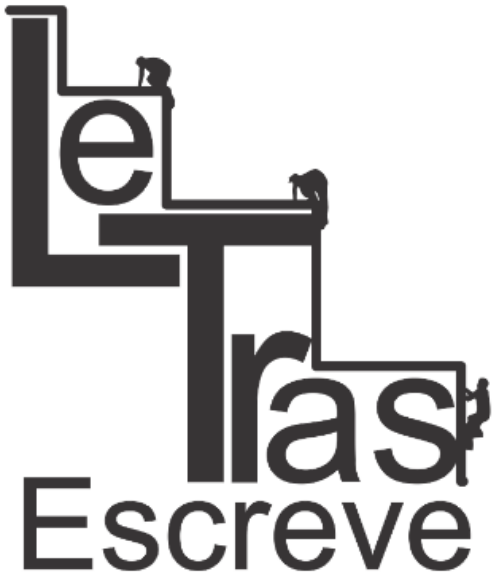

(ISSN 2238-8060)

Nessa instância de análise, observaremos o conjunto de temas que permeiam o perfil 'Frank Sinatra está resfriado'. Para fins de análise, sugerimos quatro elementos centrais aglutinadores temáticos, usados pelo repórter para estruturar o perfil. São eles: a) Artista extraordinário e o homem ordinário; b) encenação e expectativa; c) tensionamento entre público e privado e d) matrizes de testemunho. Destacamos que esses elementos se articulam em uma rede produtora de sentido sobre o perfilado contribuindo para composição do personagem.

Ao observar o perfil de Sinatra, é perceptível a construção e os sentidos que permeiam duas faces de Sinatra, que duelam e se tensionam ao longo de toda construção do perfil: as faces entre artista extraordinário e o homem ordinário.

Nesses termos, a estruturação do artigo é explícita ao iniciar com o que seria uma aparente repetição do que seria o Sinatra já conhecido publicamente: o artista arrogante e egocêntrico 
que carrega as marcas da crise de exposição e às demandas de uma carreira cruel e exigente.

\begin{abstract}
Sinatra estava fazendo um filme que agora o aborrecia e não via a hora de terminá-lo; estava cansado de toda falação da imprensa sobre seu namoro com Mia Farrrow, então com vinte anos, que aliás não deu as caras naquela noite; estava furioso com um documentário da rede de televisão CBS sobre a vida dele (...) e que, segundo se dizia, invadia sua privacidade e chegava especular sobre suas ligações com os chefes da máfia...
\end{abstract}

Então, Sinatra se afastou do banco em que estava e foi andando em direção a Ellison com aquele seu gingado arrogante. $O$ ruído dos seus passos eram os únicos que se ouvia na sala. Então, olhando para Ellison com uma sobrancelha ligeiramente erguida em sorriso malicioso (...) 'Não gosto da maneira como está vestido', disse Sinatra ...

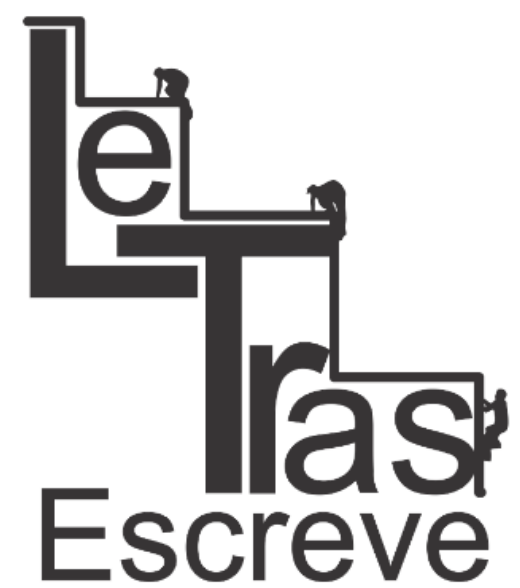

(ISSN 2238-8060)

Esse artista vai se humanizando ao longo da narrativa do repórter e termina como um homem ordinário, com defeitos e atributos de uma pessoa comum, práticas e hábitos corriqueiros como o de observar uma moça na parada do sinal de trânsito, uma cena trivial sem a expectativa de um reconhecimento dramático digno de cenas públicas entre fãs e seus ídolos.

As marcas entre as duas figuras, a do artista com hábitos extravagantes e excêntricos como a saída formada por um staff profissional, a ida em avião particular para uma mansão; e a do homem com hábitos rotineiros e não plenamente perfeitos no trato com a afetividade entre família e pessoas mais próximas, vão se entrelaçando na construção de um personagem dúbio que responde a expectativas de rituais, modos de ser/estar exigidos pelo mundo público e o mundo privado. 
Frank Sinatra faz as coisas pessoalmente. No Natal, ele vai pessoalmente comprar dezenas de presentes para os amigos mais chegados e para família, e nunca do tipo de jóia que eles apreciam, de suas cores preferidas, do tamanho de suas camisas e vestidos. Quando, há pouco mais de um ano, a casa de um músico amigo seu foi destruída e a mulher dele morreu num deslizamento de terra em Los Angeles, Sinatra foi ajudá-lo pessoalmente (...)

O mesmo Sinatra que fez tudo isso pode, de uma hora para outro, explodir numa terrível fúria de intolerância se alguns de seus chapas comer algum pequeno deslize ao cumprimento de alguma tarefa (...) quando um de seus homens the trouxe um cachorro quente com ketchup que, como se sabe, Sinatra abomina, ele jogou o frasco no homem...

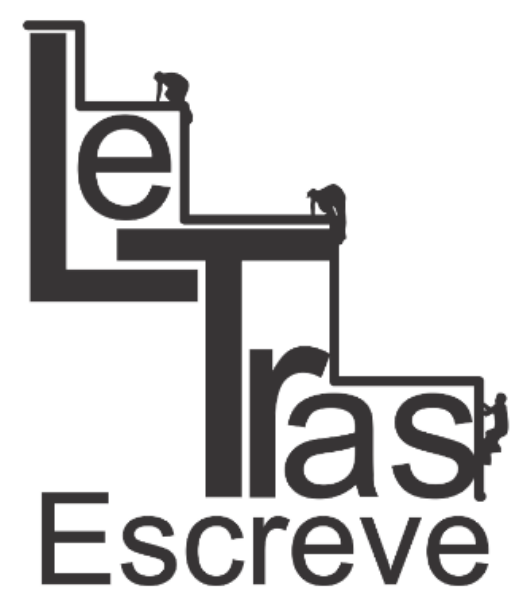

(ISSN 2238-8060)
A relação entre esses dois mundos, em si tão tensionada na construção do perfil, materializa-se na própria narrativa em um quase clímax - trecho do perfil em que são narradas as expectativas e apreensão da equipe de Sinatra sobre o momento do documentário feito sem o consentimento do artista sobre sua vida, que seria exibida por uma rede de televisão com potencial de potencializar uma trajetória de crise e tensões entre Sinatra e a opinião pública.

O que se esperava eram bastidores privados de um homem com seus problemas pessoais (relação com a máfia italiana, dramas pessoais), que para a imagem pública seria um problema; mas o que veio da cena midiatizada foi o que mais o representa publicamente, sua música.

Sinatra conversava com alguns amigos sobre o programa da CBS. A certa altura, ele disse: 'Oh, foi muito divertido'. (...) 'Mas acho que Jack Gould tinha razão em seu artigo do Times de hoje', disse Sinatra. 'Deviam ter tratado mais do homem, e não tanto da música' ... 
Um problema para quem queria ver o homem Sinatra, o homem que de tão comum pedia uma humanização, a mesma construída em torno de sua identidade como pai, filho e marido na perspectiva dos mais próximos aos seus.

Essa figura não-pública ganha contornos mais definidos nas falas e relatos dos mais próximos afetivamente do artista; relatos que contrastam com as falas curtas, ríspidas e objetivas de Sinatra quando ele fala por ele mesmo.

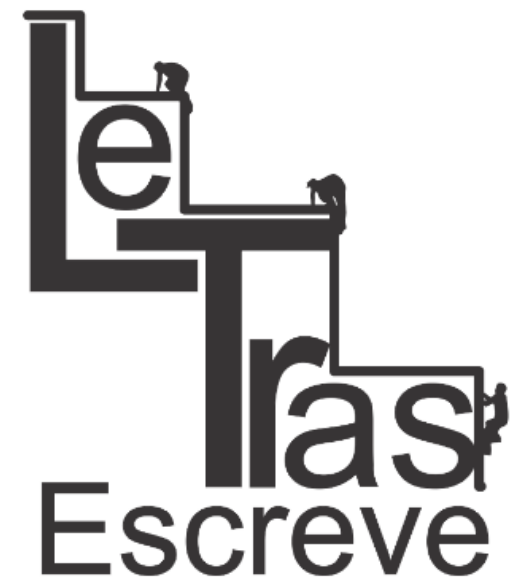

Mais tarde Jim Mahoney e outro homem entraram na salinha, e então falou-se da morte de Dorothy Kilgall em Nova York, na manhã daquele dia. Durante anos, ela foi inimiga figadal de Sinatra, e ele passou a destratá-la no seu show que fazia em seu nightclub. Agora, mesmo com ela morta, ele não transigiu em seus sentimentos. 'Dorothy Kilgall morreu', repetiu ele saindo da salinha em direção ao estúdio. "Bem, acho que vou ter que reformular todo meu show'.

'Por que a gente não grava essa merda', exclamou ele, olhando para a cabine de vidro onde estavam o diretor, Dwight Hernion, e sua equipe. Eles pareciam estar de cabeça baixa, concentrando na mesa de controle. (... ) ' Por que a gente não grava essa merda', repetiu Sinatra. (...)

(...) Nancy (filha), que na sua infância se sentia rejeitada quando ele adormecia no sofá em vez de lidar atenção, mas tarde entendeu que o sofá era um dos poucos lugares no mundo em que Frank conseguia ter alguma privacidade, onde seu rosto famoso não seria o centro das atenções nem provocaria uma reação anormal nas pessoas. Ela entendeu também que as coisas normais sempre foram negadas ao seu pai: a infância dele foi marcada pela solidão e pela busca de atenção, e desde que a conquistou, nunca mais conseguiu ficar a sós consigo mesmo.

Esse tensionamento entre o público e privado se revela nesses embates em torno dessa dupla face de Sinatra, incompletas por si mesmas, complementares, embora dual. Cenas, falas,

https://periodicos.unifap.br/index.php/letras

Macapá, v. 8, n. I, Io sem., 2018 
comportamentos, jogos de cena se entrelaçam no embate entre esses dois espaços, que produzem tensões entre o 'Sinatra do press-release' e o Sinatra 'comum dos mortais'. No relato do fiIho, Frank Jr, o contraste fica evidente:

Uma das coisas que contribuíram para a fama precoce do seu pai, diz Frank Jr, foi a criação de um 'Sinatra do press- release', concebido para 'distingui-lo do comum dos mortais, separado da realidade: de repente, se tornou Sinatra, o magnata eletrizante, Sinatra que é supranormal, não sobre-humano, mas supranormal. E aí é que está', continua Frank Jr, ' a grande falácia, a grande mentira, porque Frank Sinatra é normal, é um sujeito com quem você pode topar em uma esquina. Mas esse outro ser, essa figura supranormal, afetou Sinatra da mesma forma que afeta qualquer um que assista a um dos seus especiais na televisão ou que leia um artigo de revista sobre ele ...'

Essa afetação do Sinatra pela figura supranormal produzida pela força do press-release e a necessidade de exposição rivaliza na construção do perfil entre um jogo de representações que giram em torno da figura em um jogo que se aproxima da encenação e expectativa do que viria a ser o produto desse tensionamento entre o mundo público e privado que produzia, por sua vez, o artista extraordinário e o homem ordinário.

Parte desse jogo de representação do perfilado remete e brinca com a figura do dublê para um Sinatra que dupla e encena a todo instante como figura pública.

Por um lado é gaiato - por exemplo quando fala e brinca com Sammy Davis, Jr; Richard Conte, LizaMinelli, Bernice Massi, ou qualquer outra pessoa do show bunisses que senta à mesa; por outro lado quando balança a cabeça ou acena para os chapas mais próximos (...), ele é o II Padrone. Ou melhor ainda, ele é um dos que na velha Sicilia seriam chamados

https://periodicos.unifap.br/index.php/letras

Macapá, v. 8, n. I, Io sem., 2018 
de (...) homens de respeito: homens que são ao mesmo tempo grandiosos e humildes, homens amados por todos e generosos por natureza (...)

Essa encenação cria expectativas em uma narrativa porosa que diz, mas não referenda, a figura do Sinatra nesses dois homens que convivem e se misturam, na lógica da afetação entre os dois mundos que se misturam e se rivalizam na moldura que dá forma ao perfilado.

Pela especificidade da construção do perfil em análise, uma série de vozes dá musculatura para construção do perfilado; tornam-se personagens também na estratégia do repórter de composição do perfil com distintas matrizes de testemunho, que marcam memórias humanizadoras convivendo com impressões retiradas da observação do Sinatra do press-release.

\begin{abstract}
'Por que a gente não grava essa merda?', exclamou ele, olhando para cabine de vidro onde estavam o diretor, Dwigth Hernion, e sua equipe (...) 'Por que a gente não grava essa merda, repetiu Sinatra. (...) De repente, ouviu-se a voz de Hernion no amplificador de som, dizendo calmamente: 'Ok, Frank, você não se importaria em repetir...' 'Sim, eu me importaria sim', retrucou Sinatra.

Em 1944, quando se mudou para Califórnia e comprou uma casa protegida por uma sebe de três metros de altura em Lake Toluca, descobriu que a única maneira de fugir do telefone e outras formas de invasão era sair em seu barco a remo acompanhado de alguns amigos, uma mesa de carteado e uma caixa de cerveja, e passar a tarde inteira a bordo. Mas segundo Nancy (filha) ele procurou, na medida do possível, ser como todo mundo. Chorou no dia do casamento dela, porque é muito sentimental e sensível...
\end{abstract}

A natureza do relato que transita nos espaços e resulta dos tensionamentos entre os dois Franks estão permeadas de encenação e expectativas sobre o que as vozes testemunham e

https://periodicos.unifap.br/index.php/letras

Macapá, v. 8, n. I, Io sem., 2018 
suas respectivas intenções de moldar o personagem em disputa mediada pelo narrador, no caso, o repórter onipresente.

\subsection{Composição}

Desde o título - "Frank Sinatra has a cold" - o perfil permeia as potencialidades e escolhas composicionais do repórter Gay Talese. Certamente, em sintonia com a trajetória conteudística, sabemos que não será um perfil - e para que faça jus ao gênero - com apenas a persona já conhecida de "The Voice": o cantor, o ídolo, a celebridade,um dos homens mais ricos e influenciadores da América nós já o conhecemos ou, ao menos, podemos inferir. "Ele está resfriado" nos alerta e preconiza este perfil, ou seja, Frank Sinatra - além das persona (pública) já legitimada e quiçá invejada - também, e aqui, é vulnerável, mais uma humano constipado, ainda que tal situação possa aglomerar uma série de riscos,

Neste contexto, e para desbravar a composição deste perfil, operacionalizamos a seguinte divisão analítica: a) foco narrativo, b) espaço e c) tempo.

Em relação ao foco narrativo, ainda que o cerne no plano de conteúdo seja as inúmeras particularidades de uma pessoa física (ao menos, em nosso objeto empírico), a detenção do poder de representação está num narrador onisciente seletivo. Ainda que o repórter Gay Talese sinaliza ao leitor traços de um narrador observador, por exemplo, nos constata que o cantor está num "canto escuro do balcão entre duas loiras atraentes" ou "Leo Durocher, um dos amigos mais próximos de Sinatra, jogava sinuca numa salinha no fundo do bar." Mas, esse aparente "nar-

https://periodicos.unifap.br/index.php/letras

Macapá, v. 8, n. I, Io sem., 2018 
rador observador" facilmente se materializa em um narrador que

"tudo vê", inclusive a dimensão psicológica de seu perfilado:

(...) Dexter vive à procura de textos que Sinatra possa estrelar. Ele sempre se preocupa quando está entre estranhos na companhia de Sinatra, porque sabe que ele faz aflorar nas pessoas o que elas têm de melhor e de pior - alguns homens se mostram agressivos, algumas mulheres se põem a fazer charme, outros ficam na órbita do ídolo, avaliando-o com ceticismo. A mera presença de Sinatra intoxica o ambiente de algum modo, e às vezes ele próprio, quando não está muito bem, como naquela noite, se torna intolerante e tenso, e então é fatal: manchetes nos jornais.

No trecho em questão, e para chancelar esse ponto de

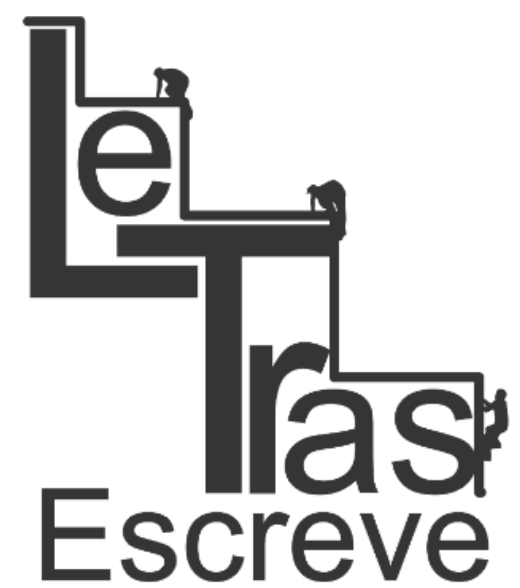

(ISSN 2238-8060) vista, muitas vezes o narrador onisciente se utiliza da coleta de informações, seguramente obtidas de algumas das entrevistas com pessoas próximas ao ídolo. $\mathrm{O}$ amigo Dexter, por exemplo, afirma o repórter: "Ele diz sentir necessidade de protegê-lo, chegando recentemente a confessor, num momento de autorevelação: 'Por ele eu seria capaz de matar'." Pouco adiante no perfil, o narrador onisciente reitere o "aspecto siciliano" do perfilado - "É uma característica que Sinatra prefere, ainda que não admita." - sendo que para comprovar tal premissa convoca novamente seu "narrador observador":

Testemunhei algo desse lado siciliano de Sinatra no verão passado no Jilly's, em Nova York, aliás a única vez em que vi Sinatra de perto antes daquela noite no clube da Califórnia. (...) Naquela noite, dezenas desses admiradores alguns dos quais amigos distantes de Sinatra, outros meros conhecidos, outros nem uma coisa nem outra, surgiram na frente do Jilly's. Eles se aproximaram do bar como se fosse um santuário. Tinham vindo prestar seus respeitos. Eram de Nova York, Brooklyn, Atlantic City, Hoboken. Entre eles havia velhos atores, ex-lutadores de boxe, trompetistas fatigados, políticos, um menino com uma bengala. 
Além de reforçar o chamariz espacial que Sinatra provocava, o repórter Gay Talese em diversas vezes convoca seu ponto de vista, enquanto narrador observador e/ou por meio do enunciado afirmativo de algum entrevistado próximo ao perfilado. E vale problematizar os motivos dessa insistente estratégia: será que a narrativa jornalística permite (apenas) um narrador onisciente? Ao contrário de obras literárias e cinematográficas, o jornalismo apoia-se numa reconstituição (e, por isso, também uma fragmentação) de uma verdade pressuposta com pretensões realistas.

Não à toa, no tecido textual deste perfil, a todo o momento Gay Talese necessita ancorar seu narrador onisciente com um narrador-observador e/ou demais fontes. Não basta aqui articular as singularidades do perfilado, o perfil jornalístico é um gênero que exige provas em enunciados concretos (do próprio repórter, pessoas próximas ou o perfilado), legitimadoras das definições ali desenhadas daquela persona em questão. Podemos inferir que a estratégia de Talese na incorporação de um narrador onisciente seja para auxiliar no processo da própria sedução textual: ao escalar um narrador onipresente, estou autorizado (na qualidade de voz narrativa) a dar mais saltos (e riscos) de quem pode/deve ser esse personagem, afinal "sou o narrador que tudo sabe".

O trânsito do foco narrativo não é exclusivo da categoria do ponto de vista. As categorias espaço e tempo se apóiam nas aventuras investigativas desse narrador-repórter. Na categoria espaço é perceptível o grau de detalhamento presente em alguns cenários, desde aspectos da mobília até a iluminação local. Em sintonia, o repórter deflagra também o "espaço social" (em ter- 
mos de capital social do perfilado), eis alguns exemplos:

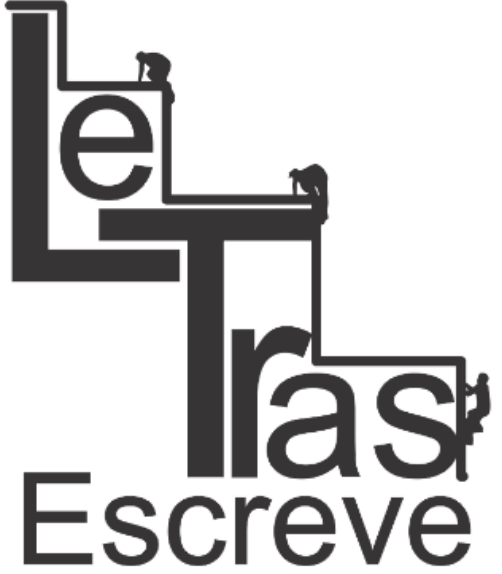

(ISSN 2238-8060)

(no bar Jilly's) Outros que, de um modo ou de outro, conseguiam chegar perto o bastante para apertar a mão de Sinatra, não o faziam; apenas tocavam-lhe o ombro, ou a manga da camisa, ou simplesmente ficavam perto o bastante para que ele os visse e, depois de receberem de Sinatra uma piscadela de reconhecimento, um aceno, um movimento de cabeça, ou depois de serem chamados pelo nome (ele tem uma memória fantástica para nomes), davam meia-volta e iam embora. Tinham conseguido o que queriam. Tinham prestado seus respeitos.

(briga no bar da Califórnia) O ruído dos seus passos eram o único som que se ouvia na sala. Então, olhando para Ellison com uma sobrancelha ligeiramente erguida e um sorriso malicioso, Sinatra perguntou: "Você está esperando uma tempestade?". Harlan Ellison deslocou-se um pouco para o lado. "Por que você está falando comigo?" "Não gosto da maneira como você está vestido", disse Sinatra. "Sinto muito incomodá-lo", disse Allison, "mas eu me visto do jeito que gosto."

Já em relação ao tempo narrativo, observa-se a presença constante do uso de gerúndios como recurso composicional. Vale recordar que toda narrativa jornalística (bem como toda enunciação concreta) abarca uma reinvenção de um tempo já ocorrido, isto é, o tempo do discurso se distingue do tempo do acontecimento. A presença de inúmeros verbos no gerúndio auxilia numa construção de sentido de proximidade do leitor com os fatos (passados) ali narrados, como se tais ações se "presentificassem" diante da leitura do texto, como no exemplo:

(momento da gravação em estúdio) Rodaram o VT para Sinatra. Ele só o viu por uns cinco minutos, depois começou a balançar a cabeça e disse para Hernion: "Esqueça, esqueça. Você está perdendo tempo. $\mathrm{O}$ que temos aqui", disse Sinatra fazendo um sinal com a cabeça em direção a sua imagem no vídeo, "é um homem resfriado". Então saiu da cabine de controle,

https://periodicos.unifap.br/index.php/letras

Macapá, v. 8, n. I, Io sem., 2018 
ordenando que todo o trabalho do dia fosse anulado e a gravação fosse adiada até que ele se recuperasse. (...)

Lá pelas quatro da manhã, Frank Sinatra saiu com seu grupo do The Sahara, alguns com os copos de uísque na mão, bebericando enquanto andavam na calçada em direção aos carros; então, de volta ao The Sands, entraram no cassino. Ainda estava cheio de gente, as roletas a mil, os jogadores de dados gritando num canto.

Ainda que não possível neste trabalho radiografar o "vai e vem temporal" presente no perfil "Frank Sinatra has a cold" - as conversas de bar, as inúmeras brigas e constrangimentos, os momentos com os fãs, as gravações em estúdio, flashback do passado, os momentos familiares - verifica-se não apenas nesse perfil a evidência de muitas elipses dos momentos de entrevistas e, por conseguinte, das inúmeras informações abordadas nesses tempos. O que, por fim, se registra em texto são alguns flagrantes desses espaços/tempos (das inúmeras fontes e conversas com o perfilado) que certamente favorecem ao efeito de realidade evocado, e sob a responsabilidade, do narrador-repórter.

\section{Considerações finais}

Observamos que o gênero perfil, como modalidade de narrativa e textual no jornalismo, exige ainda ampliação de estudos para melhor compreensão de suas construções de sentido e potencialidades para o próprio campo. Não à toa, é um gênero caracterizado sob distintas perspectivas conceituais na teorização sobre o jornalismo, o que resulta em divergências sobre sua especificidade enquanto gênero.

Como exposto, de um lado, algumas abordagens conceituais defendem o perfil como uma subdivisão avançada do gênero 


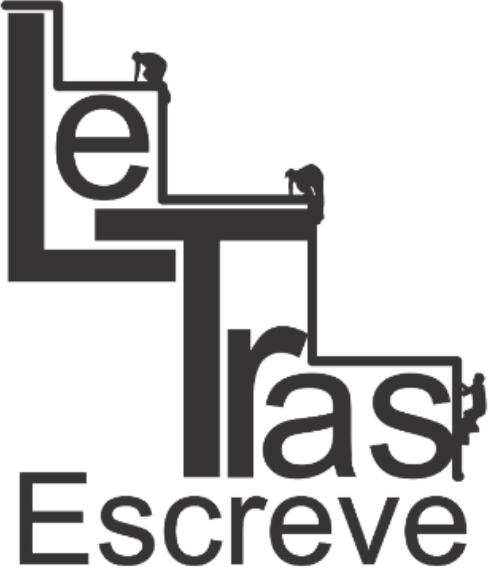

(ISSN 2238-8060) entrevista, abarcando inúmeras classificações. De outro lado, outras vertentes defendem e apóiam o perfil como mais uma modalidade do gênero reportagem, por demandar uma trajetória investigativa no processo de apuração tão complexa como a confecção de uma reportagem. Ademais, nas poucas obras referentes ao perfil jornalístico, em especial no contexto brasileiro, o que se observa é uma sistematização em manuais com técnicas de como fazer do que uma reflexão teórica sobre as especificidades do gênero.

Um elemento incontestável, contudo, é a centralidade no gênero de uma personagem. Isto é, o repórter capta fragmentos de uma fonte e ressignifica para construção de uma personagem dentro de um espaço/tempo, materializada em um gênero jornalístico nominado perfil. Em 'Frank Sinatra está resfriado' esse movimento, operador por um narrador onisciente ancorado em um narrador observador, está presente ao longo de todo o perfil.

Além disso, nota-se uma flexibilidade na operacionalização das categorias de espaço/tempo presentes no processo de composição de um gênero que está presente no perfil em tela. Em intersecção com os aspectos composicionais, verifica-se na esfera de conteúdo temático uma estratégia de compor o personagem, a partir de suas idiossincrasias e ambiguidades em um tensionamento constante envolvendo o mundo público/privado e o Sinatra do press release e o Sinatra ordinário, com a legitimação do testemunho do repórter observador e/ou relato de fontes próximas ao perfilado.

Destaca-se que a consagração do perfil em tela é a ruptura com as estratégias padronizadas de construção desse gênero: o contato direto e prolongado com o perfilado.

https://periodicos.unifap.br/index.php/letras

Macapá, v. 8, n. I, Io sem., 2018 
A análise do Perfil 'Sinatra está resfriado', na perspectiva de Bakhtin, leva a uma problematização sobre o poder do repórter na construção e ressignificação da identidade de uma pessoa para compor um personagem. Destacamos, nesse sentido, o perfil como produto de uma relação de poder que opera dispositivos, a partir da linguagem para construção de sentido. Para Gomes (2000), o jornalismo, como um fato da língua, organiza discursivamente por meio de uma função testemunhal pelas vias da confirmação, vigilância e hierarquização de fatos tornados públicos.

O nosso entendimento para futuras investigações, considerando a análise realizada, parte de um pressuposto conceitual de que o discurso jornalístico é um dispositivo em que a linguagem, segundo Gomes $(2003$,$) tem a propriedade organizadora da$ apreensão de mundo. Para tanto, a compreensão da autora é a de que as palavras têm efeitos e não palavras como efeitos. A autora parte da compreensão de Deleuze de que toda informação é uma palavra de ordem. Nesse sentido, a linguagem não é informativa ou comunicativa, mas palavras de ordem.

É possível, nesse sentido, a problematização para futuras investigações a abordagem do gênero perfil como um discurso permeado por palavras de ordem que, no jornalismo, assume uma dimensão significativa ao organizar a discursividade com efeitos de realidade, a partir de uma estratégia de confirmação de um veredicto sobre a persona, vigilância e hierarquização de atributos, modos de ser e pensar sobre o outro (a fonte perfilada).

Nessa configurada relação de poder entre fonte e jornalista, estão processos de legitimação que tornam o jornalismo co-

https://periodicos.unifap.br/index.php/letras

Macapá, v. 8, n. I, Io sem., 2018 


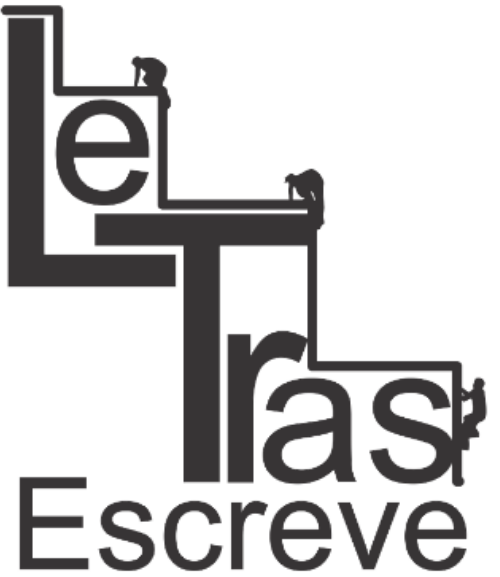

(ISSN 2238-8060)

mo discurso na função testemunhal e organizadora do mapa que orienta a apreensão do mundo. Essas matizes estão marcadas no perfil analisado, sobretudo, nas escolhas composicionais destacadas na análise apresentada.

Ou seja, a abordagem bakhtiniana usada como opção teórico-metodológica na análise realizada permite a compreensão de uma radiografia sobre a narrativa, capaz de alavancar elementos que estruturam a composição textual que, por sua vez, realçam as relações e dispositivos ancorados na linguagem jornalística como aspectos fundamentais para imersão analítica mais qualitativa do gênero perfil, considerando as perspectivas do jornalismo como discurso peculiar sobre uma dada realidade.

\section{Referências}

BAKHTIN, Mikhail. Marxismo e Filosofia da Linguagem. São Paulo: Hucitec, 1992.

Estética da Criação Verbal. São Paulo: Martins Fontes, 1992.

BULHÕES, Marcelo. Jornalismo e literatura em convergência. São Paulo: Ática, 2007.

COIMBRA, Oswaldo. 0 texto da reportagem impressa: um curso sobre sua estrutura. São Paulo: Ática, 2004.

GOMES, M.R. Jornalismo e Ciências da Linguagem. São Paulo: Edusp, 2000.

Poder no jornalismo: discorrer, disciplinar e controlar. São Paulo: Hacker, Edusp, 2003.

LAGE, Nilson. A reportagem: teoria, técnica de entrevista e pesquisa jornalística. 2a ed. São Paulo: Record, 2002.

https://periodicos.unifap.br/index.php/letras

Macapá, v. 8, n. I, Io sem., 2018 


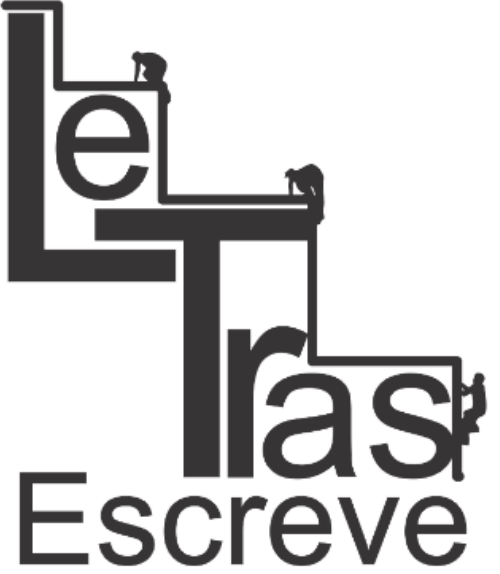

(ISSN 2238-8060)
MEDINA, Cremilda de Araújo. Entrevista, o diálogo possível. São Paulo: Ática, 1995.

MELO, José Marques de. A opinião no Jornalismo Brasileiro. Petrópolis: Vozes, 1985.

MORIN, Edgar. "A entrevista nas Ciências Sociais, no Rádio e Televisão". In: MOLES, Abraham A. et. alli. Linguagem da Comunicação de Massa. Petrópolis: Vozes, 1973.

SODRÉ, Muniz; FERRARI, Maria Helena. Técnica de Redação: o texto no jornalismo impresso. Rio de Janeiro: Francisco Alves, 1986.

TALESE, Gay. Fama e Anonimato. São Paulo: Companhia das Letras, 2004.

WOLFE, Tom. Radical Chique e o Novo Jornalismo. São Paulo: Companhia das Letras, 2005.

RODRIGUES, R. H. Análise de gêneros do discurso na teoria bakhtiniana: algumas questões teóricas e metodológicas. Linguagem em (Dis)curso, Tubarão, v. 4, n. 2, p. 415-440, jan./jun. 2004.

SILVEIRA, Maria Inez. Análise do Gênero Textual: Concepção Sócio-Retórica. Maceió: UFAL, 2005.

Enviado em 30/06/2017

Aceito em 19/12/2017 